\title{
Transported to New South Wales: medical convicts 1788-1850
}

\author{
DAVID RICHARDS
}

Between 18 and 20 January 1788 all 11 of the First Fleet of ships arrived at Botany Bay, New South Wales, to establish a penal colony. Under the command of the governor designate, Captain Arthur Phillip, they had set sail from Spithead on 13 May 1787. On board were 11 medical men, 10 of whom were sailing as free men. The exception was John Irving, a surgeon who had been sentenced to transportation for seven years after his conviction at Lincoln Assizes in March 1784 for stealing a gold cup in Grantham. He was was the first of several doctors who were transported to Australia as convicts. Some of them, notably William Redfern, ${ }^{12}$ William Bland, ${ }^{23}$ and Kevin Izod O'Doherty, ${ }^{45}$ became important and respected members of the colonies' medical and political establishment. There were others, too, ${ }^{67}$ many of them unrecognised, and here 1 give an account of the circumstances of, and contributions to Australian society by 16 convict doctors who arrived between 1788 and 1850.

\section{A mixed bag}

Some 162000 men and women were transported to Australia between 1787 and 1868 . Not surprisingly, among them there were a few medical men, particularly since among their ranks there were men of differing skills and training, intellectual and practical abilities, and ethical persuasions. In late eighteenth century Britain there were only about 3100 qualified practitioners (according to Simmons' Medical Register for 1783) and probably up to twice as many unqualified.

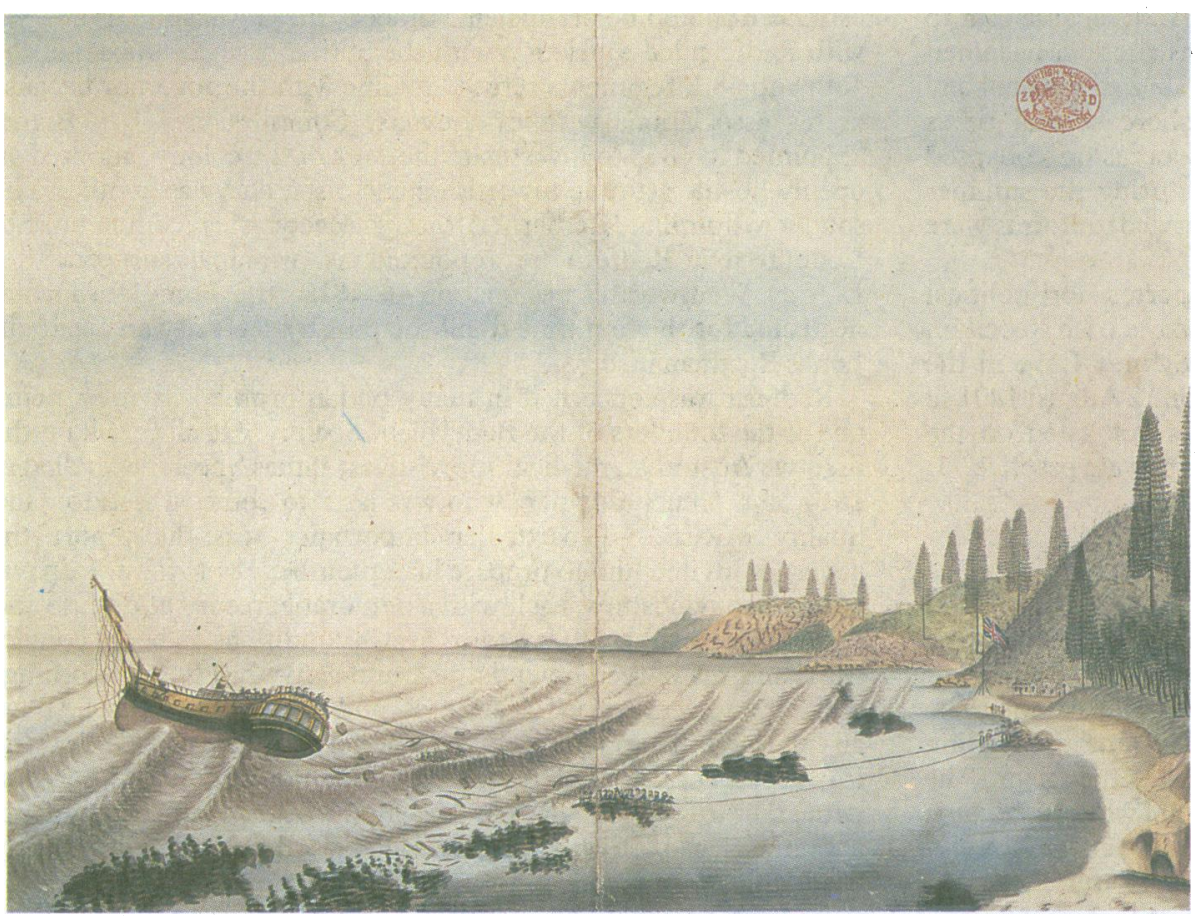

"A view of the west side of Norfolk Island and the manner in which the crew and provisions were saved out of His Majesty's ship the Sirius." (By permission of the British Museum (Natural History).)

Surgeon John Irving would probably have arrived at Norfolk Island on this voyage. A second colony had been established there within weeks of the First Fleet's arrival at Sydney Cove in 1788: two years later supplies in New South Wales were running so low that Governor Phillip sent more than one third of the convicts to Norfolk Island on the Sirius, which was wrecked on arrival. A few years later ex-naval surgeon William Redfern was sent there as assistant surgeon.
Similarly, the term "convict" was used to cover prisoners sentenced for crimes of very differing degrees and types of guilt. Most out and out criminals then found guilty of committing major offences received the death penalty, whereas many of those guilty of minor offences that technically still carried a capital charge were instead transported for seven or $\mathbf{1 4}$ years or for life. In practice, however, the period of sentence made little difference since few convicts, having served their sentences, had enough money to buy a passage home.

\section{The first medical convict}

On arrival in New South Wales, where Phillip established the first settlement at Sydney Cove, the first group of some 730 convicts were put to manual work in clearing the ground and erecting the first buildings. The first medical convict, John Irving, who had been "bred to surgery," seems to have been given privileged duties as he was employed as an assistant at the hospital (initially a tent set aside for the purpose and later a portable building erected in July 1790). ${ }^{8}$ Indeed, his medical talents had been recognised even before the First Fleet sailed, since he acted as surgeon's mate to the convicts in April 1787 when John Turnpenny Alltree, surgeon of the transport Lady Penrhyn, was absent on sick leave.

Most of the First Fleet convicts and the marines sent to guard them were healthy on arrival, but dysentery and scurvy soon affected them, and there was plenty of work for Irving and the four colonial surgeons. Evidently Irving must have impressed the principal surgeon, John White, for on 28 February 1790 Governor Phillip emancipated him for "his meritorious behaviour" and he became the first convict to receive an absolute pardon. Furthermore, since the surgeons had found him "a useful man," he was now officially appointed as assistant to the surgeons at Norfolk Island, where a second colony was established in March 1788. He returned to Sydney in late 1791 and was sent to work with assistant surgeon Thomas Arndell at the second settlement established at Parramatta. Awarded a land grant of 30 acres, by October 1792 he had nine acres of maize under cultivation and was having a house built for him.

Although Governor Phillip had in 1790 and 1791 made requests to London for confirmation of Irving's appointment not until Governor Hunter's arrival in September 1795 was official sanction received. Sadly Irving died a few days before the news arrived. Although suffering the stigma of transportation, he proved himself to be a valued member of the new colony.

\section{Pardoned to practise}

At least two other medical convicts were living in New South Wales during Irving's time. Daniel Kelly, who arrived in 1790 or 1791 , was given an absolute 
remission of his sentence on 4 June 1793. He was employed as an assistant to the surgeon at Toongabbie and in February 1794 received a land grant of 30 acres. Again he had proved his worth in the colony, for on arrival he had been recommended by the surgeon of his transport and sent to work as a medical assistant at the hospital, where. his assiduity gained him favour from Governor Phillip. It was noted that he had been "formerly a servant of his Majesty's in the medical line, and had unfortunately trespassed against the laws of his country." Some of the colonists objected to the employment of a former convict, but William Balmain, the second principal surgeon, supported him. He died in either late 1799 or early 1800.

John Francis Molloy arrived in Sydney on 14 February 1792, having been sentenced at the Kent Assizes on two counts of highway robbery. ${ }^{9}$ Although described

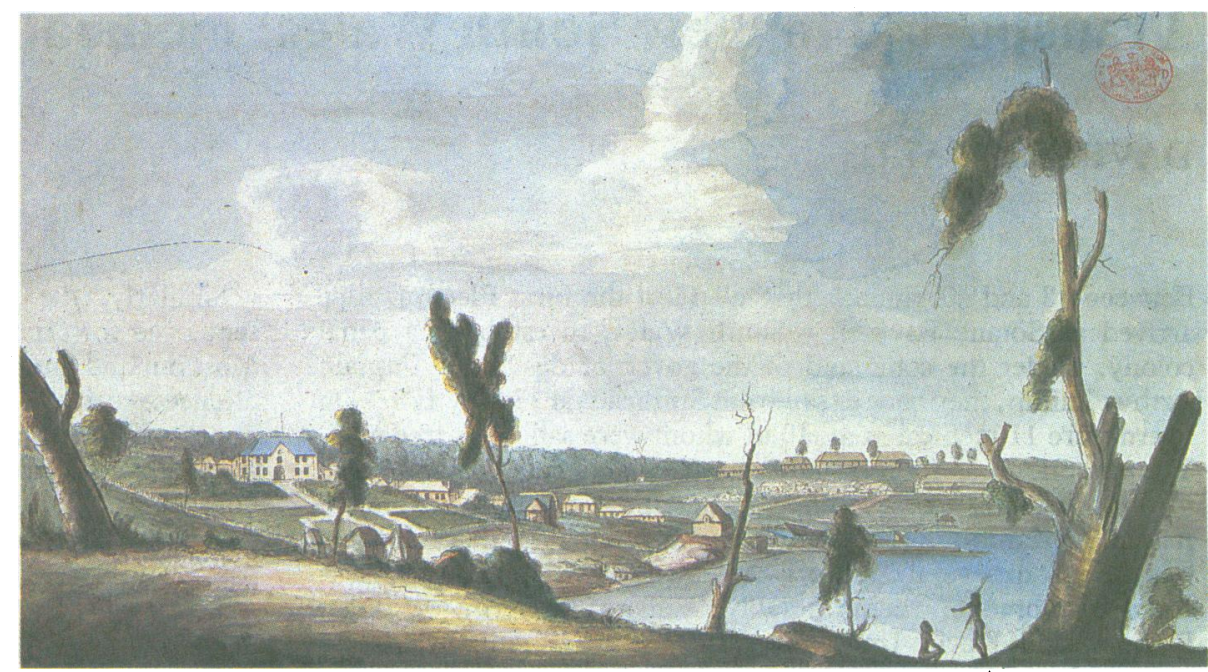

“A Partial View in New South Wales" (Sydney circa 1795) by Thomas Watling. Sydney's first hospital is the long low building on the painting's extreme right. (By permission of the British Museum (Natural History).) at his trial as a labourer, soon after his arrival he was engaged in medical duties at an outlying district on the Hawkesbury River. Even if he had not practised medicine before he left England, he might have served as a medical orderly on his voyage out on the Pitt. In 1795, when his sentence still had nearly three years to run, he received a land grant of 30 acres. He was obviously treated as a privileged person, although William Balmain had complained to Governor Hunter about the paucity of medical manpower and noted on 16 October 1795 that at the Hawkesbury "the business is entrusted to a convict who has not much professional skill."

The next medical convict to arrive, Evan Morgan, who had been "bred in the medical line" and was accordingly placed to work at the hospital, achieved fame in 1798 by secretly boarding a visiting American ship bound for China, thus escaping from the colony.

Daniel McCallum was pardoned in July 1801 "to enable him to practise his profession." On Governor King's instructions he joined the expedition to the Bass Strait in November 1802 to forestall any French attempt at colonisation. He went ashore several times around the mouth of the Yarra, but on one occasion collapsed during the heat-not surprisingly since even during the summer months of January and February 1803 heavy service uniforms were being worn.

Bryan O'Connor MD of Cork was transported for political crimes. Tried in May 1799 for his involvement in the Irish Rebellion of 1798, he was found guilty and arrived at Sydney Cove in the Mineroa on 11 January 1800 . He was pardoned on 12 August 1801 so that he could practise medicine. Since he was not listed on the colonial establishment he probably developed a private practice.

\section{A principal citizen}

The arrival of ex-naval surgeon William Redfern on the Minerva in December 1801 provides a further illustration of the different reasons which prompted a sentence of transportation. Although he arrived as a convict, Redfern was in time to become the leading doctor in Sydney and one of its principal citizens. At the age of 19 he was serving as a surgeon's mate on H M S Standard when he became implicated in a minor way in the infamous mutiny at the Nore in May 1797 by advising his men "to become more united among themselves." He expressed sympathy with some of the sailors' complaints relating to the abominable conditions in which they served. For this he was court martialled, sentenced to be shot, but reprieved on account of his age. After four years in prison he was transported. Soon after his arrival in Sydney on 14 December 1801 he was drafted as assistant surgeon at Norfolk Island and pardoned on 19 June 1803 . He returned to Sydney in 1808 and was appointed assistant surgeon at the hospital.
Before entering the navy Redfern had passed the examination of the London Company of Surgeons but had never received any written confirmation of this. Since he could not prove his qualification he volunteered to be re-examined. On 1 September 1808 he was found to be "qualified to exercise the Profession of a Surgeon \& c And consequently to fill the Situation of an Assistant Surgeon in any Department of His Majesty's Service" and thus became the first doctor to be qualified in the colony.

As an emancipist, however, Redfern, encountered vehement hostility from sections of the community. Notwithstanding acting as family doctor to both Governor Lachlan Macquarie (and indeed travelling with him on official visits throughout the expanding colony) and the influential Macarthur family, he was shunned by some who believed that convicts were social outcasts whose ostracism should be permanent. Indeed, the Governor's friendship with Redfern led to friction with the military, when officers of the 46th and 48th regiments refused to dine with the governor because of his associations with ex-convicts. Commissioner J T Bigge, appointed in 1818 to investigate the state of the colony, adopted an openly hostile attitude towards emancipists, and was another who sought to humiliate Redfern. Although Macquarie recommended to London that Redfern be appointed as principal surgeon after D'Arcy Wentworth's resignation in 1818, the home authorities neglected for the first time to fill the post by seniority and sent out James Bowman instead.

Redfern was concerned in many philanthropic activities, being one of the founders of the Benevolent Society. He also took on the first two Australian medical apprentices, James Sheers, who died in 1814, and Henry Cowper, who was later to come to London and qualify MRCS. Of particular importance was the report the governor invited him to prepare in September 1814 after the arrival of three convict ships, each with a deplorable record of disease and preventable deaths. He reviewed health conditions on board convict ships and made recommendations under five headings-clothing, diet, air and ventilation, cleanliness, and medical assistance. Above all he urged the appointment of experienced surgeons. Macquarie forwarded copies of Redfern's report to the London authorities, with the irony that one of the first surgeon superintendents appointed in 1816 was James Bowman, the man subsequently destined to deny Redfern the principal surgeonship.

Redfern resigned on Bowman's arrival, devoting himself to private practice. In an attempt to lighten Redfern's disappointment Macquarie appointed him a magistrate but after representations from London was forced to remove him from this office because he was an ex-convict. Redfern amassed a considerable fortune from his medical practice and his business activities, which included a directorship of the Bank of New South Wales and interests in the wool industry and in wine making. He visited England in 1821 as a 
delegate of the emancipists and after returning to Sydney in July 1824 came again to London in 1825 . He again returned but only to give up his practice in 1826; in 1828 he retired to Edinburgh, where he died in 1833, aged 55, leaving a large estate in New South Wales.

\section{From lampoons to the legislature}

William Bland, another naval surgeon who arrived in Sydney via Hobart as a convict in June 1814, illustrates another cause for transportation. The son of a leading London obstetrician, he had qualified and joined the navy. While serving as a 23 year-old surgeon on $\mathrm{H}$ M S Hesper at Bombay he became involved in a wardroom altercation with Robert Case, the ship's purser, who issued a challenge. Bland fought a duel with pistols with him on 7 April 1813 and wounded him fatally. Found guilty of murder he was recommended for mercy and sentenced to seven years' transportation. On arrival in Sydney he was sent as prisoner to the Castle Hill Lunatic Asylum, the colony's first mental hospital, established in 1811 , which was in fact an old barn surrounded by a stockade. Bland received his pardon on 27 October 1815 and began private practice early in 1816. He had applied for a colonial post but having been offered the assistant surgeonship at Port Dalrymple in Van Diemen's Land (Tasmania) he declined to submit himself, in order to prove his credentials, to examination by D'Arcy Wentworth, Redfern and Major West, on the grounds that he was better qualified than any of them.

Bland was a flamboyant figure in his early life and in September 1818 was sentenced to a year's imprisonment in Parramatta gaol after his conviction for writing a poem lampooning Governor Macquarie's predilection for having his name inscribed on public buildings. He returned to private practice and by 1826-7 was on the staff of the Sydney Dispensary, founded to provide treatment for the sick poor. He was a patron and philanthropist and supported a number of institutions, notably the free grammar school, Sydney College, opened in January 1835 . He was later concerned in the foundation of the University of Sydney, but his name was dropped from the senate under pressure that former convicts should not take part in the management of the institution. From 1821 onwards, indeed, Bland was very much concerned with the cause of emancipists and later associated in the formation of the Australian Patriotic Association.

He became an elected member of the legislature in 1843, and although he lost his seat in 1848 he served again in 1850 and later served on the legislative council between 1858 and 1861. Bland's medical experiences were also important-in 1832 he carried out the first operation for aneuryism in Australia, reported in the Lancet. He died of pneumonia in 1868, and was accorded a state funeralthus firmly removing any stigma of having been transported.

\section{Mixed fortunes}

The next medical convict, Patrick Smith, enjoyed a brief stay in New South Wales. He arrived from Cork on 26 July 1817 on board the Chapman, on which he had served as doctor's mate to Alexander Dewar, the surgeon superintendent. Twelve convicts were killed and 28 were wounded en route, and a court of inquiry was set up by Governor Macquarie. The governor decided to send the captain, Dewar, and members of the military guard home to face further charges. In so doing he was forced to send home as witnesses a number of the convicts-among them Smith, who testified that he had not heard anything from the convicts of a mutiny but that he had heard prisoners crying for mercy before they were shot dead. An Old Bailey court in January 1819 acquitted those charged, but since the convicts were incompetent to give evidence without a free pardon they were set at liberty.

Another medical convict "Dr" Connolly had arrived by 1826 , when he was summoned to examine an army sergeant who subsequently died from an apoplectic seizure. A coroner's inquiry was held, and after exonerating Dr Ivory, the military surgeon, noted that "the ignorance of Connolly ... will prevent his again imposing himself on those who have not had an opportunity of being informed of his incompentency as a Medical Practitioner," and withdrew his ticket of leave (probationary release).

Henry White arrived in Hobart on the Earl St Vincent in August 1826, having left behind a wife and family and been found guilty of forgery at the Old Bailey the previous September. ${ }^{10}$ A London surgeon, he had been concerned in the South Sea Company and been tried on three charges. He had pleaded guilty to the lesser charge (forging the signature of a witness), which carried the penalty of transportation, and thus avoided a sentence on two other charges of forging money, which was punishable by death. Posted first to a government farm at Emu Plains and then as assistant surgeon to an expedition to Western Port, his health suffered, and when the new settlement was abandoned he was sent to Port Stephens without ticket of leave or remission as an assigned convict with the Australian Agricultural Company. His sentence ended in October 1832 and he entered private practice, settling eventually at Windsor. In November 1842 he married the daughter of a prominent landowner. He is said to have fought a duel with an army captain in Novemebr 1842 and to have discovered a rich lode of copper in March 1845.

William Strang, a 20 year old former Glasgow medical student, arrived on the Mermaid on 6 May $1830 .{ }^{11}$ He had led a double life-by day a respectable student and by night a habitué of taverns, where he got in with the wrong company by mixing with criminal groups. He took part in at least two robberies and was one of the few people committed for transportation by Scottish courts.

Alexander McDonald reached Sydney on the Lord Lyndoch on 18 October 1833.
The Military Hospital, Sydney's third, built in 1816 with convalescents from the 48th Regiment walking around its grounds. (By permission of the National Maritime Museum). 
James Bowman, principal surgeon, asked the governor for McDonald's services at Liverpool hospital, but the governor decided not to permit the employment of convicts in the medical profession, presumably following some misdemeanour by another as yet anonymous medical convict. T L Mitchell's expedition to the River Darling in 1835 included among its members a convict doctor, Dr Souter, who reported on seeing pockmarked aborigines.

\section{The last convicts}

The final two medical convicts to arrive by 1850 , two young Irishmen, had been found guilty of a political crime-namely, being concerned in the Young Ireland Movement. John Martin, a medical student at Trinity College Dublin, was transported but on being pardoned in 1854 returned to Ireland. A more romantic and colourful story is that of Kevin Izod O'Doherty, who arrived with Martin in Hobart via Sydney on 31 October 1849. He had thrice been tried, with the jury twice disagreeing. At his third trial he was found guilty of treason, on the grounds of his concern in the publication of the Irish Tribune, in which he told the British what he thought of them and exhorted the Irish to take action against their oppressors. In sentencing him to transportation the Dublin judge declared that "I have never read any publications more dangerous, more wicked, more clearly designed to excite insurrection, rebellion and revolution than those publications which emanated from your press."

In Van Diemen's Land Doherty was soon offered his ticket of leave and was expected to earn his living; nevertheless, he experienced difficulties in view of the few inhabitants of the area where he had to live. He later came to Hobart and entered hospital practice.

He received a conditional pardon in mid-1854 and was allowed to live anywhere but the British Isles. He tried his luck in the goldfields of Victoria but then made a clandestine visit to Ireland to see Eva O'Kelly, a young nationalistic poetess with whom he had corresponded since his trial. They were secretly married in London in August 1855 and went to live in Paris, where Kevin worked at the Hôpital Pitié and studied at the Paris School of Anatomy. When he received a full pardon in $\mathbf{1 8 5 6}$ he returned with his wife to Dublin, from where in 1857, nine years later than he had intended, he graduated from the College of Surgeons of Ireland. His friend Dr James Quinn was appointed the Catholic Bishop of Brisbane and persuaded him to return to Australia. He settled in Queensland and became a leader in medical, church, political, and public affairs. He was elected to the Colony's legislative assembly and was responsible for introducing Queensland's first Health Act. He continued to support the Irish cause, however, and came home in 1885 to stand for election in the North Meath constituency. He received a hero's return to Dublin and was granted the freedom of the city. He took his seat in the House of Commons, but after the defeat of the Home Rule Bill became disillusioned and resigned. He returned to Australia, living in Sydney and later Queensland, where he undertook a variety of part time public appointments. Alas he went blind and died in 1905 aged 81 .

In the early years of New South Wales, and indeed of the other Australian colonies, there was a very clear dependence on Britain for the supply of qualified doctors. Some came out as surgeons on convict or emigrant ships and some as members of the official colonial staff. Others served a tour of duty in the armed forces, came out as emigrants and as free or assisted settlers seeking land and fortune (perhaps from gold prospecting), or came for health reasons seeking cures for ailments such as tuberculosis. Additionally a small band of men came not freely but as transportees, and from this group emerged such doctors as Redfern, Bland, O'Doherty and others who played an important part in the development of medicine in Australia. Two hundred years on from the arrival of the First Fleet we salute their contributions, some of them following on from the expressions of youthful ebullience that led to their transportation and thus effecting Britain's loss and Australia's gain.

Receipt of travel grants from the Wellcome Trust and the Trent Polytechnic Research Fund is gratefully acknowledged. These enabled me to spend two months in Australia during 1986 consulting source material for a preliminary study of medical emigration to Australia during 1788-1850.

The illustrations reproduced here can be seen in two exhibitions: "Australia 200-Episodes in the Growth of a Nation" at the National Maritime Museum, Greenwich, London, until April 1988 and "First Impressions: The British Discovery of Australia" at the Natural History Museum, London, 8 January-20 March, 1988.

Department of Social Studies, Trent Polytechnic, Nottingham NG1 4BU DAVID RICHARDS, MSC, PHD, head of department

\section{References}

Except where indicated the sources of data on which this paper is based are to be found principally in the Historical Records of Australia.

1 Dunlop NJ. Med f Austral 1928;i:294-310.

2 Ford E. Med ₹ Austral 1955;ii:41-53.

3 Dunlop NJ. Med f Austral 1924;ii:471-6, 522-9.

4 Patrick R. From convict to doctor. In: Pearn J, O'Carrigan C, eds. Australia's quest for colonial health. Brisbane, Queensland: Department of Child Health, Royal Children's Hospital, 1980:65-73.

5 Patrick R. From convict to doctor. In: Horsewhip the doctor. St Lucia, Queensland: University of Queensland, 1985:88-100.

6 Cleland J B. Proc R Soc Med 1937-8:31:1439-42.

7 Cleland JB. Med J Austral 1952;i:475-8.

8 Gray AJ. Foumal of the Royjal Austmalian Historical Society 1954-5;40:316-31.

9 Darvall R: Med I Austral 1975;i:475-8.

10 Bowden K. The Westem Port setlement and its leading personalities. Cheltenham, Victoria: South Eastern Historical Association, 1970:41.

11 Donnachie I. Scottish Ecomomic and Social History 1984;4:21-38. 